\title{
An Applied Research On Experiential Marketing In M-commerce
}

\author{
Minzhen Yang,Bin Huang \\ School of Media Studies \& Humanities ,Zhejiang University City College ,Hangzhou, China \\ E-mail: 562200309@qq.com
}

\begin{abstract}
The rapidly developing M-Commerce has changed the developmental model of small and medium-sized enterprises. A traditional marketing model is a single supply chain. Thus, in the environment of E-Commerce, enterprises should change their marketing models. Based on the requirements of the customers, Experiential Marketing becomes the developing power of enterprises, enabling the communication and largely quantizing the interests between businessmen and consumers. In this essay, the examples of $\mathrm{Li}$ Ning and Durex can perfectly explain the application in the environment of M-Commerce.
\end{abstract}

Keywords-component; M-Commerce;the

customers' requirements; Experiential Marketing

*Minzhen Yang is the first author; Bin Huang is the correspondence author.

\section{INTRODUCTION}

With the rapid development of E-Commence, the breakthrough of mobile communication technology and the constant changes of policy environment, a new Ecommerce-M-Commerce has developed gradually. However, with the rapid development of economic, MCommerce is in a furious competition. This task is based on the results of the existing researches at home and abroad, combined with the social background of China, to study the applications of the experiential marketing in the environment of mobile electronic commerce and to help the small and medium-sized enterprises breakthrough the mode.

\section{ON CURRENT SITUATION AND COUNTERMEASURES OF E-BUSINESS \\ DEVELOPMENT OF SMALL AND MEDIUM-SIZED ENTERPRISES IN CHINA}

The data of Media Research shows, the transaction siz e of M-Commerce market in China was 156.7 billion yuan i $\mathrm{n} 2011$, with the amount rising by 60.9 percent. It is expecte $\mathrm{d}$ that the size of M-Commerce market in 2012 will reach 25. 15 billion yuan, and it will be more than 100 billion yuan $i$ n 2015 to 104.67 billion yuan . [1]As for the scale of the use rs , the data of Media Research shows that the scale of MCommerce users in China will increase to 0.92 billion in 20 11 ,with the amount rising by 58.6 percent .The expected si ze of M-Commerce users in China in 2012 will reach to 14 6 million , and it will reach to 348 million in 2012.[2]
The tremendously developmental potential of MCommerce attracts many small enterprises to participate in it.

The director of China Electronic Commerce Association, Song Ling thinks that M-Commerce is convenient, flexible and with low cost, so it can be used possibly whenever and wherever. These characteristics of M-Commerce are suitable for small and medium-sized enterprises. From the development of these small and medium-sized enterprises, M-Commerce will help them improve the efficiency of their productivity and it is also beneficial to small and mediumsized enterprises to achieve a leap-type development, enhancing the strength of enterprises.[3]

However, there are still some limitations for small and medium-sized enterprises in the $\mathrm{M}$ - Commerce market according to the data of "China M-Commerce Research Report in 2011".According to effective samples of 1023, most of the basic information will be weak, only 43 companies establishing a complete ERP system , less than 584 companies establishing financial systems, more than 57 percent ; and 42 companies, less than 5 percent, will have OA systems; 115 companies, more than 11 percent, will have CRM systems; 131 companies, less than 13 percent, will have desktop PC e-commerce systems. Influenced by traditional ideas, the ways of purchasing and using the software for the small and medium-sized enterprises are still relatively weak. Their marketing model is also single and the universal use of electronic commerce and mobile commerce business are also not very good.[4]

If the small and medium-sized enterprises want to break through this limitation, they should strengthen the application of mobile terminal technology and build the database. Through the data of the database , they can find the information of customers and locate the orientation of customers, productions and service .It can also change the traditional way of marketing and it serve the customers as its core, using the new marketing mode which is called "experienced marketing” to change their own disadvantages.

\section{M-COMMERCE AND EXPERIENTIAL MARKETING}

\section{A. M-Commerce}

M-Commerce consists B2B (Business-to-business), B2C (Business-to-consumer) and C2C(Consumer-to-consumer) based on wireless terminal units cell phones and PDA . It contains Banking Business, Wireless CRM Transaction, Mobile Office, shopping and Information Service. 
Compared to the traditional E-Commerce, M-Commerce is a syncretic product of E-Commerce and Mobile-data Service. It has a mess audience, a convenient way of commercial activities, a reliable credit mechanism and a personalized service. It also has a quick and cheaper way of payment.

\section{B. Experiential Marketing}

Customers experience the quality of service and products provided by the company by watching , listening and trying, and then They will acknowledge it, love it, and ultimately purchase it. Such kind of marketing is called Experiential Marketing. It aims at meeting the experiential needs of customers, with Serving the products as a platform, with tangible products as its carriers; it also produces and sells high-qualified products and works at reducing the distance between enterprises and customers.

With the development of the society and the improvement of products, customer stands in a definitely higher position and will have higher requirements on enterprises and products. They need the experience of products and service. Thus the foreground of Experiential Marketing is so broad that it will open up a new space and bring life to the interaction between enterprises and customers. An enterprise can survive in the fierce marketing competition only by grasping and fulfilling the marketing ideas as soon as possible.

Whether in traditional E-Commerce or in new ECommerce, customer's requirements and experience always rank the first, for the core of E-Commerce is the service.

\section{Experiential marketing's effects on M-Commerce}

In the environment of M-Commerce, M-Commerce requires a precise data analysis on its customers and different personalized experience for various customers. Following are the benefits:

- Building a M-Commerce data and accelerating the reaction to the change of it can give marketingchanging feedback to the enterprises.

- The optimization and integration of basic MCommerce Service enable the customers to gain information and experience the products and service more conveniently. It also enlarges the market of $\mathrm{M}$ Commerce by changing potential customers into real ones.

- Enterprises will improve the design of existing Mobile Terminal, develop versatile Mobile Service and utilize WAP wireless devices that are easy to measure. Thus, it provides the rapid service convenient of M-Commerce.

- The composition and win-win base of M-Commerce industrial chain.

\section{Experiential Marketing's characters on M-Commerce}

- Individuation

There is a tremendous divergence between individuals, so in M-Commerce, Experiential Marketing must have a strong personality in order to attract individual participation and interaction.
- Interaction

In M-Commerce, the participation of customers is needed to form an interactive behavior. Thus, the effect of Experiential Marketing is the performance.

- Emotionality

Experiential Marketing pays more attention to the emotional input. In the emotional interaction in $\mathrm{M}$ Commerce, it prompts the friendship sentiments and fulfills the emotional need of the customers.

\section{- Continuity}

In M-Commerce, the customer's experience will not fade away when they experience the first time, it has continuity.And sometimes it would be changed into another new feeling. So Experiential Marketing has a long-term effect. Once customers are satisfied with the experience, they would be more loyal to the companies.

- Intangibility

Experiential Marketing emphasizes on the unforgettable and vivid experience which can only be perceived.

\section{THE CASES’ ANALYSIS OF EXPERIENTIAL MARKETING IN M-COMMERCE}

About the question of how the small and mediumsized enterprises use the new model of experience marketing. Firstly, they should draw good experience from the successful marketing cases and try to understand their own limitations. Secondly, according to the actual condition of themselves, they should make the experienced marketing strategies which are suitable for their own and improve their brand images.

\section{A. Experiential Marketing pattern of life}

Experiential Marketing of life___analysis of "Li Ning: breathe lightly to hear the run"

In 2011, Li Ning, a well-known brand, advocated a new proposition "The World follows me, all things breathe lightly" to the running paradigm.

The activity was sponsored by its Sina Microbolg. It can be widely disseminated. Users can tape the sounds of their breathing or the surroundings when they are running. Then they can use either phones or computers to upload these sounds to the Internet. On the event page, all kinds of sounds can be found, users can also guess and vote. The most interesting one is the dandelion model. Flying dandelion seems like the mood of running. It highly matches the advantages of ideas and products.

This activity is a creation of the integration in Social Network and Mobile Service. Different from the common Geo-location Services, it stretches to the consumption process and sublimates the interests into a spiritual level in which interaction is available. To those unlimited brands, $\mathrm{Li}$ Ning advises that they should emancipate their minds and be more creative before and during his consumption.

Sports has always been the pursuit of people's leisure activity. Li Ning uses this activity to seek the lifestyle of customers. So as to attract the customers and establish a stable customer groups, it transforms company's products and brands into a symbol of lifestyle, even the symbols of the 
identity, the identification of status through the use of mobile devices and networks.

\section{B. Experiential Marketing pattern on entertainment Experiential Marketing ——Durex Baby APP for iPhone"}

In April 2010, “Durex” made a marketing survey report . It is said that the condom-use proportion had been decreased with the reduction of ages. Faced with such a dilemma, "Durex" cooperated with "Apple" and designed a mobile game_- "Durex Baby APP for iPhone" which allows people to download and experience automatically for education. They also made a film called "Crazy App: Durex baby plan”. In order to attract young lovers, it explains the game and pictures which may appear.

It is a simple baby-feeding game for lovers who both own the iPhones. After downloading this application, they just put two iPhones together and then a lovely baby will appear in the mobile phones. In the following time, the baby will cry or make a noise at odd intervals, so the users must try to compose him for all their art by milking and teasing him, and sometimes even singing and hugging .

If they do not want to be disturbed by his shouting noise, they can use their phones scan the QR code on Durex packing box, then the anti-disturbing mode will be unlocked.

In this case, we learn that Durex utilized the potential of Mobile Games and iPhone applications and reached its marketing purposes. By entertaining customers, it has also improved its Corporation Images and Sales. Compared with traditional marketing, such marketing seems more relaxing、 vivid and humane.

In the activities of M-Commerce, they combine the mobile device and the transmission carrier ingenious. They also take full account of Customers' demands of the experience of entertainment and use the currently popular games to provide a reverse service.

It is a great significance for the development of $\mathrm{M}$ Commerce to use the experience marketing in a complete $\mathrm{M}$ Commerce platform.

- $\quad$ Enterprises

If the company wants to improve the useful value of the products, they should comply with customers' personalized demands. It is also necessary to build the two-side communication with the customers, to collect customers' information and to enhance the needs of customers. Thus, it is easy to get a better development.

- Customers

It is easy to make a better option to purchase the products if using an experience way to understand the company and its products.

\section{CONCLUSION}

China Mobile has a large group of customers, MCommerce is developing rapidly during these years and its developmental potential is tremendous. But as the limitations of national policy, the mobile operators, banks, businesses, consumers and other factors, China is still in primary developing stage of $\mathrm{M}$-Commerce .There are still some problems needed to be solved, such as the transaction security, the model of business and the acceptance for consumers. The government and enterprises should strengthen their contact and coordination to explore a set of security strategy which is strict in the technology, management and laws in order to solve the security problems and relieve the threats. It will also helpful to build the environment which is suitable for activities of M-Commerce, to promote the rapidly development of M-Commerce.

In the face of vigorous development of M-Commerce, the small and medium enterprises should take the initiative strategy and focus on the development of product, the update of product and the upgrade of service. They should also accurately orientate the customers and understand their needs. Then, they can provide the customers with the corresponding experiencing service and improve its competition ability. It is also necessary to establish and expand business database, for it is beneficial to win the opportunity of experience marketing.

\section{REFERENCES}

[1] Ai Media.2012 Q2 quarterly monitoring of China Mobile E-commerc e market,URL: http://www.iimedia.cn/34283.html.

[2] China food machinery and equipment Network, The first half handlin g conditions of China Mobile E-commerce market,URL:http://www.f oodjx.com/News/Detail/81226.html.

[3] Technology age of Sina. Mobile E-commerce: The mode revolution o f minor enterprise development,URL :http://tech.sina.com.cn/i/2008-0 7-01/14182296079.shtm.

[4] Electricity supplier News.,Mobile E-commerce into the new darling o f the market, . URL:http://www.shopex.cn/eschool/news/2011/1212/1 142.html.

[5] F.Gao,"Analysis on the essence of Experientil marketing Economic a nd Trade”,199,pp.141-142,2011.

[6] D.P.Zhang.S.X.Chen,“Experience marketing: review and future prosp ect of value”, Marketing in China,1,pp.41-46,2011.

[7] C.M.Zhang, "Chinese small and medium-sized enterprises of mobile electronic commerce application development report", Beijing,Mobile Internet Research Center, 2011.

[8] C.H.Wang.,"Experience marketing case study", Tianjin,Nankai Unive rsity press, 2010,pp.6-9.

[9] C,Q.Gao,"Experience marketing and its mode of experience",Journal of Jilin province economic management cadre,3,pp.46-49,2010.

S.X.Wen,"Based on the WAP of mobile electronic commerce marketing mode and Strategy Research",Beijing:,Beijing University of Posts and Telecommunications press, 2010. 